\title{
REORIENTASI SANKSI PIDANA DALAM PERTANGGUNGJAWABAN KORPORASI DI INDONESIA
}

\author{
Rizqi Purnama Puteri, Muhammad Junaidi, Zaenal Arifin \\ Magister Hukum Universitas Semarang, Semarang \\ rizqiputeri.rp@gmail.com
}

\begin{abstract}
ABSTRAK
Tujuan penelitian ini adalah bagaimanakah orientasi sanksi pidana terhadap korporasi dalam hukum positif di Indonesia, bagaimanakah reorientasi formulasi yang seharusnya atas sanksi pidana terhadap korporasiKUHP sekarang ini belum mengatur masalah pertanggungjawaban pidana korporasi. Pentingnya mengatur Pertanggunjawaban pidana korporasi ada dalam satu ketentuan umum KUHP sebagai pedoman bagi undang- undang khusus di luar KUHP sehingga tercipta keseragaman dan konsistensi dalam pengaturan mengenai pertanggungjawaban pidana korporasi.. Metode penelitian yang digunakan adalah yuridis normatif dengan menggunakan data sekunder. Hasil penelitian dapat disimpulkan bahwa orientasi korporasi sampai saat ini belum diatur oleh KUHP dan terdapat undang-undang khusus di luar KUHP sudah mengatur korporasi sebagai subjek hukum pidana, tetapi terlihat untuk mengisi kekosongan hukum dan tidak menjamin kepastian hukum terhadap pemidanaan korporasi. Reorientasi pada formulasi kebijakan atas sanksi pidana korporasi yang ideal dengan menjadikan korporasi sebagai subjek hukum pidana serta menekankan pada konsistensi dalam hal penentuan kapan suatu tindak pidana dikatakan sebagai tindak pidana korporasi, siapa yang dapat dipidana atas kejahatan korporasi, serta sanksi yang sesuai terhadap korporasi. Saran penelitian adalah melakukan reorientasi dan reformulasi kebijakan dalam peraturan perundang-undangan yang telah ada dan Konsep KUHP sebagai pedoman umum serta segera mengesahkan RUU KUHP.
\end{abstract}

\section{Kata kunci : Reorientasi: Sanksi Pidana; Korporasi}




\title{
REORIENTATION OF CRIMINAL SANCTIONS IN CORPORATE LIABILITY IN INDONESIA
}

\author{
Rizqi Purnama Putri, Muhammad Junaidi, Zaenal Arifin Master \\ of Law, Semarang University, Semarang rizqiputeri.rp@gmail.com
}

\begin{abstract}
Considering that the Criminal Code has not yet regulated the issue of corporate criminal liability. The importance of regulating corporate criminal liability is contained in a general provision of the Criminal Code as a guideline for special laws outside the Criminal Code so as to create uniformity and consistency in the regulation of corporate criminal liability. How is the orientation of criminal sanctions against corporations in positive law in Indonesia, and how is the formulations reorientation that should be of criminal sanctions against corporations. The research method used is normative juridical using secondary data. The results of the study can be concluded that the corporate orientation to date has not been regulated by the Criminal Code and there are special laws outside the Criminal Code that have governed corporations as subjects of criminal law, but are seen to fill the legal vacuum and do not guarantee legal certainty towards corporate criminal prosecution. Reorientation of policy formulation on ideal corporate criminal sanctions by making corporations as the subject of criminal law and emphasizing consistency in determining when a crime is said to be a corporate crime, who can be convicted of corporate crime, and appropriate sanctions against the corporation. Research suggestions are to reorient and reformulate policies in existing laws and regulations and the Criminal Code Concept as a general guideline and immediately pass the Criminal Code Bill.
\end{abstract}

Keywords: Reorientation; Criminal Sanctions; Corporation 


\section{A. PENDAHULUAN}

Kejahatan korporasi tergolong sebagai white collar crime yang menggunakan modus operandi yang canggih dan dapat juga berdimensi transnasional dimana dilakukan lintas Negara dan teritorial. Gabungan dari kedua kuali kasi tersebut menghasilkan ruang lingkup kejahatan yang luas dan dampak kerugian yang sangat besar. ${ }^{1}$ Orang-orang yang terlibat dalam tindak pidana korporasi mempunyai fungsi, tugas, dan peranannya masing-masing. ${ }^{2}$

Korporasi yang menjalankan bisnis dalam bidang lingkungan hidup juga telah melakukan pembakaran hutan dan lahan. Tindak pidana dalam kejahatan lingkungan hidup yang melakukan ialah seseorang atau perorangan atau badan hukum atau korporasi di era globalisasi industri sering terjadi dilingkungan yang penuh dengan perusahaan-perusahaan yang beroperasi dapat mencemari dan merusak lingkungan yang dalam sistem pengelolaannya melanggar aturan yang berlaku ${ }^{3}$. Kasus yang telah dilakukan oleh korporasi yaitu,

1. Tahun 2019, Polisi telah menetapkan 14 perusahaan sebagai tersangka kebakaran hutan dan lahan (karhutla), per Selasa (24 September). Sebelumnya, data per Senin (23 September) menunjukkan terdapat sembilan perusahaan yang berstatus tersangka. Penambahan tersangka perusahaan terjadi di Lampung sebanyak lima korporasi. Kelima korporasi tersebut yaitu PT Sweet Indo Lampung (SIL), PT Indo Lampung Perkasa (ILP), PTPN 7, PT Paramitra Mulya Lampung (PML), dan PT Sweet Indo Lampung (SIL). Sebelumnya telah menetapkan PT AP sebagai tersangka. Berikutnya, Polda Riau menetapkan PT Sumber Sawit Sejahtera (SSS) sebagai tersangka. Kemudian, PT Hutan Bumi Lestari (HBL) (sebelumnya disebut sebagai Bumi Hijau Lestari) ditetapkan sebagai tersangka oleh Polda

\footnotetext{
${ }^{1}$ Budi Suhariyanto, Pertanggungjawaban Pidana Korporasi Berdasarkan Corporate Culture Model Dan Implikasinya Bagi Kesejahteraan Masyarakat,Jurnal Rechtvinding Volume 6 No. 3 Desember 2017 hal 442

2 Kristian, Hukum Pidana Korporasi, Kebijakan Integral (Integral Policy) Formulasi Pertanggungjawaban Pidana Korporasi Di Indonesia, Bandung: Nusa Aulia, 2014, hal. 3

${ }^{3}$ Mujiono, Formulasi Korporasi Sebagai Subjek Hukum Pidana Dalam Regulasi Lingkungan Hidup Di Indonesia, Jurnal Lentera Hukum Volume 628 April 2019, hal. 54
} 
Sumatera Selatan. Lalu, PT Mega Anugerah Sawit (MAS) menyandang status sebagai tersangka karhutla di Jambi. ${ }^{4}$

2. Tahun 2011 perkara PT. Giri Jaladhi Wana yang diajukan sebagai terdakwa oleh Kejaksaan dan dituntut ke pengadilan tindak pidana korupsi, ${ }^{5}$ setelah terlebih dahulu direktur utamanya (SW) dipidana (berdasarkan Putusan Nomor 908/ Pid.B/2008/PN.Bjm tanggal 18 Desember 2008 yang mana putusan tersebut telah dikuatkan dengan Putusan Nomor 02/PID/SUS/2009/ PT.BJM tanggal 25 Februari 2009 dan kasasi terdakwa telah ditolak berdasarkan Putusan Nomor 936 K/Pid.Sus/2009 tanggal 25 Mei 2009). Majelis hakim melalui Putusan Nomor 812/Pid.Sus/2010/PN.Bjm memutuskan persis sama dengan tuntutan yaitu menyatakan PT GJW telah terbuk secara sah dan meyakinkan bersalah melakukan ndak pidana korupsi secara berlanjut sebagaimana dalam dakwaan primer, karenanya kepada PT GJW dijatuhkan pidana denda sebesar Rp1.300.000.000,- (satu miliar ga ratus juta rupiah) serta pidana tambahan berupa penutupan sementara PT GJW selama enam bulan. ${ }^{6}$

3. Kasus Sport Center Hambalang: Kasus korupsi proyek Sport Center Hambalang oleh Komisi Pemberantasan Korupsi (KPK) yang menyebabkan negara dirugikan sebesar Rp. 463,66 miliar. Menurut temuan BPK, uang yang dikeluarkan pemerintah untuk Hambalang dari kontrak Rp 1,2 triliun baru Rp 471 miliar, tapi karena masih ada sisa Rp 8 miliar maka jadi Rp 463 miliar, termasuk untuk pengadaan barang jasa. Dalam kasus ini telah menyeret mantan Menpora Andi Malarangeng, Sekjen Kemenpora Wafid Muharram, dan mantan Ketua Umum Partai Demokrat Anas Urbaningrum ${ }^{7}$.

Korporasi menurut hukum pidana Indonesia tidak sama dengan pengertian korporasi dalam hukum perdata. Pengertian korporasi menurut hukum pidana lebih luas daripada pengertian menurut hukum perdata.

$4 \quad$ Https://Regional.Kontan.Co.Id/News/Sampa i-Hari-Ini-14-Perusahaan-JadiTersangkaKebakaran-Hutan-Dan-Lahan Di Akses Pada Tanggal 24 September 2019

${ }^{5}$ Budi Suhariyanto, Progresivitas Putusan Pemidanaan Terhadap Korporasi Pelaku Tindak Pidana Korupsi, Jurnal De Jure Volume 16 Nomor 2 (Juni 2016), hal. 207.

${ }^{6}$ Budi Suhariyanto, Putusan Pemidanaan Terhadapn Korporasi Tanpa Didakwakan Dalam Perspektif Vicarious Liability, Jurnal Yudisial Volume Volume 10 Nomor 1 (April 2017), hal 2728.

${ }^{7}$ Zaenal Arifin, Tindak Pidana Korupsi Dalam Pengadaan Barang Dan Jasa Pemerinta $h$, Jurnal Hukum Responsif Vol. 5 No. 5, Oktober 2017, Fakultas Hukum Universitas Panca Budi, Medan, 2017 hal 59 
Penjelasan Korporasi dalam Pasal 10 Perma No. 13 Tahun 2016 menjelaskan bahwa $^{8}$ :

Pengurus adalah organ korporasi yang menjalankan pengurusan korporasi sesuai anggaran dasar atau undang-undang yang berwenang mewakili korporasi, termasuk mereka yang tidak memiliki kewenangan untuk mengambil keputusan, namun dalam kenyataannya dapat mengendalikan atau turut mempengaruhi kebijakan korporasi atau turut memutuskan kebijakan dalam korporasi yang dapat dikualifikasikan sebagai tindak pidana.

Subjek tindak pidana yang dikenal dalam KUHP adalah orang perorangan. Dengan kata lain, hanya manusia yang dapat melakukan tindak pidana dan hanya manusia yang dapat dituntut serta dibebani pertanggungjawaban pidana. KUHP tidak mengenal korporasi sebagai subjek hukum pidana. Tetapi korporasi atur dalam beberapa undang- undang di luar KUHP yaitu Undang-Undang No. 31 Tahun 1999 tentang Pemberantasan Tindak Pidana Korupsi sebagaimana telah diubah dengan Undang-Undang No. 20 Tahun 2001, Undang-Undang No. 15 Tahun 2002 tentang Tindak Pidana Pencucian Uang sebagaimana telah diubah dengan Undang-Undang No. 8 Tahun 2010. ${ }^{910}$ Hal ini didasarkan pada Pasal 59 KUHP. Pasal tersebut menjelaskan bahwa apabila korporasi yang melakukan tindak pidana, maka pertanggungjawaban pidana dibebankan kepada pengurus korporasi dalam hal pengurus korporasi melakukan tindak pidana dalam rangka mewakili atau dilakukan atas nama korporasi tersebut. KUHP yang berlaku saat ini belum mengatur mengenai pertanggungjawaban pidana korporasi dalam arti belum mengenal korporasi sebagai subjek tindak pidana, namun beberapa undangundang ${ }^{11}$.

${ }^{8}$ Hariyadi B. Sukamdani, Korporasi Sebagai Subyek Hukum Pidana Pasca Perma No.13 Tahun 2016: Pandangan Dunia Usaha, (Makalah Seminar Dalam Rangka HUT IKAHI Ke-64 Tahun Di Hotel Mercure Ancol Jakarta Pada Hari Selasa 21 Maret 2017), hal.7.

${ }^{9}$ Barda Nawawi Arief, Kapita Selekta Hukum Pidana, Citra Aditya Bakti, Bandung, 2003, hal. $10-226$

${ }^{11}$ Andi Hamzah, Kejahatan Di Bidang Ekonomi Dan Cara Penanggulangannya, Makalah, Jakarta, 1994 hal 1 


\section{B. PERMASALAHAN}

1. Bagaimanakah orientasi sanksi pidana terhadap korporasi dalam hukum positif di Indonesia?

2. Bagaimanakah reorientasi formulasi yang ideal atas sanksi pidana terhadap korporasi?

\section{METODE PENELITIAN}

Penelitian ini menggunakan pendekatan yuridis normatif, spesifikasi penelitian ini adalah penelitian deskriptif analitis, Penelitian ini termasuk penelitian hukum normatif, maka jenis data yang digunakan adalah data sekunder, metode pengumpulan data dilakukan melalui studi kepustakaan dan studi dokumen dengan mengumpulkan dan menganalisis bahan- bahan kepustakaan serta dokumen-dokumen. Mertode analisis data yang diperlukan dalam penelitian ini adalah metode kualitatif

\section{PEMBAHASAN}

Kebijakan orientasi sanksi pidana terhadap korporasi dalam hukum positif di Indonesia belum mencapai tahap ketepatan atau kepastian hukum untuk menjadikan korporasi sebagai subjek hukum pidana. Karena banyaknya kelemahan-kelemahan pada pemberian sanksi pidana terdapat korporasi. Kelemahan yang dimaksud adalah hukum pidana Indonesia dibuat berdasarkan ajaran kesalahan individual yaitu sistem hukum pidana tidak memungkinkan penjatuhan pidana denda terhadapa korporasi, karena pihak yang dipidana dapat menggantkan dengan pidana kurungan hal tersebut diatur oleh Pasal 30 KUHP. Tidak adanya prosedur khusus dari hukum acara pidana untuk mengatur korporasi serta cara perumusan delik pidana yang selalu dimulai dengan kata "barang siapa" secara umum dimaksudkan kepada orang atau manusia.

Pandangan Gustav Radbruch secara umum diartikan bahwa kepastian hukum tidak selalu harus diberi prioritas pemenuhannya pada tiap sistem hukum positif, seolah-olah kepastian hukum itu harus ada lebih dulu, baru kemudian keadilan dan kemanfaatan. Pada kebijakan orientasi sanksi pidana korporasi, kepastian hukum itu tidak terpenuhi karena adanya ketidakjelasan 
yang terjadi dalam perumusan undang-undang mengenai korporasi. Ketidakjelasan perumusan mengenai kapan suatu korporasi dinyatakan sebagai pelaku dan kapan suatu tindak pidana telah dilakukan atas nama suatu korporasi. Ketidakjelasan perumusan mengenai perbuatan yang akan dipertanggungjawabkan melalui perumusan korporasi sebagai subjek tindak pidana. Ketidakjelasan mengenai kriteria yang digunakan sebagai pedoman untuk mempertanggungjawabkan korporasi, sebab pertanggungjawaban hukum pidana dikaitkan dengan masalah kesalahan dan unsur alasan pemaaf. Serta masalah pidana yang dijatuhkan terhadap korporasi. Jenis pidana denda yang dikenakan terhadap korporasi.

Berdasarkan hasil analisis teori kepastian hukum diatas, dapat disimpulkan bahwa orientasi sanksi pidana terhadap korporasi belum mencapai tahap yang pasti. Didasarkan pada kelemahan-kelemahan yang terlihat serta korporasi dalam hukum positif Indonesia belum menjadi subjek hukum pidana, sehingga tidak adanya aturan umum dalam KUHP yang dapat menjembatani hukum pidana umum dengan undang-undang khusus diluar KUHP. Teori pertanggungjawaban korporasi sudah dipergunakan oleh beberapa undangundangan khusus di luar KUHP dengan menggunakan model sistem pertanggungjawaban pidana yaitu pengurus korporasi sebagai pembuat dan pengurus korporasi yang bertanggungjawab, korporasi sebagai pembuat dan pengurus bertanggungjawab, dan korporasi sebagai pembuat dan juga korporasi yang bertanggungjawab ${ }^{12}$. Beberapa undang-undang yang mengatur korporasi telah memberikan perumusan mengenai pengaturan korporasi tetapi tidak dapat berjalan semestinya karena tidak ada kejelasan dalam pengaturan pertanggungjawaban pidana korporasi.

Fenomena ini ditandai dengan lahirnya Wet Economische Delichten (WED), tahun 1950 di Belanda, yang dalam Pasal 15 ayat (1) mengatur bahwa

${ }^{12}$ Mardjono Reksodiputro, Dalam Makalahnya "Pertangungjawaban Pidana Korporasi Dalam Tindak Pidana Korporasi”, (Semarang: FH-UNDIP, 1989), hal. 9 
dalam tindak pidana ekonomi, korporasi dapat melakukan tindak pidana dan dapat dipidana. Ketentuan ini kemudian ditiru oleh Indonesia melalui UndangUndang No- mor 7 Drt Tahun 1955 tentang Pengusutan, Penuntutan dan Peradilan Tindak Pidana Ekonomi ${ }^{13}$ Pengaturan dalam UU No. 7/Drt/1955 menjadi cikal bakal pertanggung- jawaban pidana korporasi dalam melakukan tindak pidana, yang kemudian diikuti beberapa peraturan perundang-undangan lain sampai dengan sekarang seperti UU Lingkungan Hidup, UU Perlindungan Konsumen, UU Perikanan, UU Narkotika, UU Pencucian Uang, UU Monopoli, UU Korupsi dan lain-lain. ${ }^{14}$

Formulasi pertanggungjawaban pidana korporasi tidak cukup dengan menyebutkan korporasi sebagai subjek tindak pidana, melainkan harus menentukan aturan mengenai sistem pidana dan pemidanaannya, sehingga diperlukan sebuah upaya reorientasi dan reformulasi yang ideal atas pertanggungjawaban pidana korporasi. Reorientasi dan reformulasi pertanggungjawaban pidana terhadap korban kejahatan korporasi antara lain meliputi ketentuan mengenai ${ }^{15}$ :

1. ketentuan mengenai kapan suatu tindak pidana dapat dikatakan sebagai tindak pidana yang dilakukan oleh korporasi;

2. siapa yang dapat dituntut dan dijatuhi pidana atas kejahatan yang dilakukan korporasi;

3. jenis-jenis sanksi yang sesuai dengan subjek tindak pidana berupa korporasi

Formulasi mengenai ketentuan tersebut harus diatur secara tegas untuk meminimalisir kemungkinan korporasi melepaskan diri dari tanggungjawab atas kejahatan yang dilakukannya. Korporasi sebagai subjek tindak pidana perumusannya berada dalam peraturan perundang-undangan di luar KUHP,

${ }^{13}$ Muladi, Penerapan Pertanggungjawaban Korporasi Dalam Hukum Pidana, Bahan Kuliah Kejahatan Korporasi, Universitas Diponegoro, Semarang, 1999, hal 2

${ }^{14}$ Eddi Rifai, Perspektif Pertanggungjawaban Pidana Korporasi Sebagai Pelaku Tindak Pidana Korupsi, Jurnal UGM Vo. 20 No. 12014 hal. 9

${ }^{15}$ Agus Sularman, Pertanggungjawaban Pidana Korporasi Kepada Korban Tindak Pidana, Jurnal Hukum Khaira Ummah Volume 122 Juni 2017, hal. 394 
pertanggungjawaban pidana kepada korporasi adalah dengan menentukan aturan atau syarat mengenai kapan suatu korporasi dikatakan melakukan tindak pidana. Undang-Undang No. 31 Tahun 1999 Jo. Undang-Undang No. 20 Tahun 2001 tentang Pemberantasan Tindak Pidana Korupsi, khususnya Pasal 20 ayat (2) ditentukan bahwa : "Tindak pidana korupsi dilakukan oleh korporasi apabila tindak pidana tersebut dilakukan oleh orang-orang baik berdasarkan hubungan kerja maupun berdasarkan hubungan lain, bertindak dalam lingkungan korporasi tersebut baik sendiri maupun bersama-sama".

Berdasarkan ketentuan tersebut, suatu tindak pidana dikatakan dapat dilakukan oleh korporasi apabila berdasarkan hubungan kerja atau hubungan lain, dan dalam lingkungan korporasi. ${ }^{16}$ formulasi tersebut seharusnya dibatasi pada orang-orang atau mereka yang mempunyai hubungan langsung dengan korporasi saja yang dapat melibatkan korporasi untuk ikut bertanggungjawab atas tindak pidana yang dilakukannya.

Formulasi tersebut dapat ditemukan pada Undang-Undang No. 15 tahun 2002 Jo. Undang-Undang No. 25 Tahun 2003 tentang Tindak Pidana Pencucian Uang, dimana dalam Pasal 4 ayat (2) ditentukan bahwa hanya pengurus yang mempunyai hubungan fungsional dalam struktur organisasi korporasi saja yang dapat melibatkan korporasi dalam pertanggungjawaban pidananya. Pasal 4 ayat (3) Undang-Undang Tindak Pidana Pencucian Uang menentukan bahwa :

"Korporasi tidak dapat dipertanggungjawabkan secara pidana terhadap suatu tindak pidana pencucian uang yang dilakukan oleh pengurus yang mengatasnamakan korporasi, apabila perbuatan tersebut dilakukan melalui kegiatan yang tidak termasuk dalam lingkup usahanya sebagaimana ditentukan dalam anggaran dasar atau ketentuan lain yang berlaku bagi korporasi yang bersangkutan".

${ }^{16}$ Evan Alroy Situmorang, Tesis Kebijakan Formulasi Pemidanaan Korporasi Terhadap Korban Kejahatan Korporasi, Magister Hukum Universitas Diponegoro_ ， Semarang, hal. $179{ }^{16}$ Ibid 
Reformulasi yang dimaksud adalah reformulasi yang berkaitan dengan ketentuan mengenai siapa yang dapat dibebani pertanggungjawaban pidana atau yang dapat dutuntut dan dijatuhi pidana. Peraturan perundang-undangan di luar KUHP yang belum mengatur hal tersebut dapat mengadopsi formulasi ketentuan dalam peraturan perundang-undangan yang telah menentukan siapa yang dapat dibebani pertanggungjawaban pidana atas kejahatan yang dilakukan oleh korporasi ${ }^{16}$. Adanya reformulasi terhadap penentuan subjek dalam tindak pidana maka akan tercipta suatu keseragaman pedoman atau aturan dalam peraturan perundang-undangan di luar KUHP yang berkaitan dengan pembebanan pertanggungjawaban pidana atas kejahatan korporasi serta akan ada kejelasan mengenai pedoman pemidanaan di dalam KUHP Indonesia dengan menjadikan korporasi sebagai subjek hukum pidana.

Ketua Penyusunan RKUHP, Muladi menyatakan bahwa pasal 47 sampai dengan pasal 53 RKUHP mengatur tentang "corporate criminal liability". Dengan dimasukkannya hal tersebut berarti bahwa bentuk pertanggungjawaban pidana terhadap korporasi berlaku umum untuk semua tindak pidana, termasuk yang berada di luar KUHP ${ }^{17}$. Rumusan pasal-pasal yang berkaitan dengan pertanggungjawaban pidana korporasi dalam RKUHP 2010 adalah sebagai berikut ${ }^{18}$ :

1. Pasal 47: "Korporasi merupakan subyek tindak pidana".

2. Pasal 48: "Tindak pidana dilakukan oleh korporasi apabila dilakukan oleh orang-orang yang bertindak untuk dan atas nama korporasi atau demi kepentingan korporasi, berdasarkan hubungan kerja atau berdasar hubungan lain, dalam lingkup usaha korporasi tersebut, baik sendirisendiri atau bersama-sama".

${ }^{17}$ Kristian, Hukum Pidana Korporasi, Kebijakan Integral (Integral Policy) Formulasi Pertanggungjawaban Pidana Korporasi Di Indonesia, Op.Cit

${ }^{18}$ Kristian, Urgensi Pertanggungjawaban Korporasi , Jurnal Hukum Dan Pembangunan 44, Oktober - Desember 2013, hal. 43 
3. Pasal 49: "Jika tindak pidana dilakukan oleh korporasi, pertanggungjawaban pidana dikenakan terhadap korporasi dan/atau pengurusnya".

4. Pasal 50: "Korporasi dapat dipertanggungjawabkan secara pidana terhadap suatu perbuatan yang dilakukan untuk dan/atau atas nama korporasi, jika perbuatan tersebut termasuk dalam lingkup usahanya sebagaimana ditentukan dalam anggaran dasar atau ketentuan lain yang berlaku bagi korporasi yang bersangkutan".

5. Pasal 51: "Pertanggungjawaban pidana pengurus korporasi dibatasi sepanjang pengurus mempunyai kedudukan fungsional dalam struktur organisasi korporasi”.

6. Pasal 52: "Dalam mempertimbangkan suatu tuntutan pidana, harus dipertimbangkan apakah bagian hukum lain telah memberikan perlindungan yang lebih berguna daripada menjatuhkan pidana terhadap suatu korporasi.

Pertimbangan sebagaimana dimaksud dalam ayat (1) harus dinyatakan dalam putusan hakim.

7. Pasal 53: "Alasan pemaaf atau alasan pembenar yang dapat diajukan oleh pembuat yang bertindak untuk dan/atau atas nama korporasi, dapat diajukan oleh korporasi sepanjang alasan tersebut langsung berhubungan dengan perbuatan yang didakwakan kepada korporasi. Pasal 44:

"Korporasi dapat dipertanggungjawabkan dalam melakukan tindak pidana".

RKUHP yang termasuk korporasi tidak hanya mencakup badan hukum, tetapi juga meliputi firma, CV, dan persekutuan yaitu badan usaha yang berdasarkan hukum perdata, bukan suatu badan hukum. ${ }^{19}$

${ }^{19}$ Ika Puspitasari, Urgensi Pengaturan Kejahatan Korporasi Dalam Pertanggungjawaban Tindak Pidana Korporasi Menurut Rkuhp, Kanun Jurnal Ilmu Hukum Vol. 20 Agustus 2018 hal. 14 


\section{E. PENUTUP}

Korporasi belum diatur dalam subjek hukum pidana Indonesia karena menganut asas "societas delinquere non potest" yaitu badan hukum tidak dapat melakukan tindak pidana. Suatu korporasi terjadi tindak pidana maka tindak pidana tersebut dianggap dilakukan oleh pengurus korporasi tersebut. Pengaturan mengenai korporasi sebagai subjek hukum pidana, memiliki tiga model pertanggungjawaban pidana korporasi. Pengurus korporasi sebagai pembuat dan pengurus korporasi yang bertanggungjawab, Korporasi sebagai pembuat dan pengurus bertanggungjawab, Korporasi sebagai pembuat dan juga korporasi yang bertanggungjawab.

Ketentuan mengenai kapan suatu tindak pidana dapat dikatakan sebagai tindak pidana yang dilakukan oleh korporasi; Siapa yang dapat dituntut dan dijatuhi pidana atas kejahatan yang dilakukan korporasi; Jenis-jenis sanksi yang sesuai dengan subjek tindak pidana berupa korporasi

Korporasi dapat dipertanggungjawabkan secara pidana hanya apabila tindak pidana yang dilakukan pengurus tersebut, adalah kegiatan yang termasuk dalam lingkup usaha korporasi. Formulasi ketentuan-ketentuan tersebut telah jelas menentukan kapan suatu tindak pidana dapat dikatakan sebagai tindak pidana yang dilakukan oleh korporasi. Ada pedoman atau batasan yang jelas mengenai kapan suatu tindak pidana dilakukan oleh korporasi.

\section{DAFTAR PUSTAKA}

\section{BUKU}

Barda Nawawi Arief, 2003, Kapita Selekta Hukum Pidana, Citra Aditya Bakti, Bandung.

Dwidja P, dan Muladi, 2015, Pertanggungjawaban Pidana Korporasi (Edisi Ketiga), Kencana Prenadamedia Group, Jakarta.

Kristian, 2014, Hukum Pidana Korporasi, Kebijakan Integral (Integral Policy) Formulasi Pertanggungjawaban Pidana Korporasi di Indonesia, Nusa Aulia Bandung. 


\section{JURNAL}

Agus Sularman, 2017, Pertanggungjawaban Pidana Korporasi Kepada Korban Tindak Pidana, Jurnal Hukum Khaira Ummah Volume 122 Juni 2017, Semarang

Budi Suhariyanto, 2016, Progresivitas Putusan Pemidanaan Terhadap Korporasi Pelaku Tindak Pidana Korupsi, Jurnal De Jure Volume 16 Nomor 2 Juni 2016, Balitbang Kemenkumham Jakarta. 2017, Putusan Pemidanaan Terhadap Korporasi Tanpa Didakwakan Dalam Perspektif Vicarious Liability, Jurnal Yudisial Volume Volume 10 Nomor 1 April 2017, Komisi Yudisial RI Jakarta. , 2017, Pertanggungjawaban Pidana Korporasi Berdasarkan Corporate

Culture Model Dan Implikasinya Bagi Kesejahteraan Masyarakat,Jurnal Rechtvinding Volume 6 No. 3 Desember 2017, BPHN Jakarta.

Eddi Rifai, 2014, Perspektif Pertanggungjawaban Pidana Korporasi Sebagai Pelaku Tindak Pidana Korupsi, Jurnal UGM Vo. 20 No. 1 2014, Yogyakarta.

Ika Puspitasari, 2018 Urgensi Pengaturan Kejahatan Korporasi Dalam

Pertanggungjawaban Tindak Pidana Korporasi Menurut RKUHP, Kanun Jurnal Ilmu Hukum Vol. 20 Agustus 2018, Banda Aceh.

Kristian, 2013, Urgensi Pertanggungjawaban Korporasi, Jurnal Hukum dan

Pembangunan 44, Oktober - Desember 2013, Jakarta

Mujiono, 2019, Formulasi Korporasi Sebagai Subjek Hukum Pidana dalam Regulasi

Lingkungan Hidup di Indonesia, Jurnal Lentera Hukum volume 628 April

2019, Jember

Rully Trie Prasetyo, 2017, Tindak Pidana Korporasi Dalam Perspektif Kebijakan Formulasi Hukum Pidana, Jurnal Hukum Khaira Ummah No.12 4 Desember 2017, Semarang

Zaenal Arifin, Tindak Pidana Korupsi Dalam Pengadaan Barang Dan Jasa Pemerintah, Jurnal Hukum Responsif Vol. 5 No. 5, Oktober 2017, Fakultas Hukum Universitas Panca Budi, Medan, 2017.

\section{ARTIKEL}

Andi Hamzah, 1994, Kejahatan di Bidang Ekonomi dan Cara Penanggulangannya, Makalah, Jakarta

Hariyadi B. Sukamdani, 2017, Korporasi sebagai Subyek Hukum Pidana Pasca Perma No.13 Tahun 2016: Pandangan Dunia Usaha, (Makalah seminar dalam Rangka HUT IKAHI ke-64 tahun di Hotel Mercure Ancol Jakarta pada hari Selasa 21 Maret 2017) Jakarta

Evan Alroy Situmorang, 2008, Kebijakan Formulasi Pemidanaan Korporasi terhadap Korban Kejahatan Korporasi, Tesis Magister Hukum Universitas Diponegoro, Semarang

Mardjono Reksodiputro, 1988, Struktur Perekonomian Dewasa ini dan Permasalahan Korban, Makalah disampaikan pada seminar Viktimologi di Universitas Airlangga, 
Surabaya, 28 Oktober 1988, Surabaya , 1999, "Pertangungjawaban Pidana Korporasi dalam Tindak Pidana

Korporasi", Semarang: FH-UNDIP, Muladi, 1999, Penerapan Pertanggungjawaban Korporasi dalam Hukum Pidana, Bahan

Kuliah Kejahatan Korporasi, Universitas Diponegoro, Semarang

\section{INTERNET}

https://regional.kontan.co.id/news/sampai-hari-ini-14-perusahaan-jaditersangkakebakaran-hutan-dan-lahan 